\title{
Position of laparo-endoscopic single-site surgery nephrectomy in clinical practice and comparison (matched case-control study) with standard laparoscopic nephrectomy
}

\author{
Milan Hora ${ }^{1}$, Viktor Eret ${ }^{1}$, Petr Stránský ${ }^{1}$, Ivan Trávniček ${ }^{1}$, Tomáš Ürge ${ }^{1}$, Jiři Ferda², Fredrik Petersson ${ }^{3}$, Ondřej Hes ${ }^{4}$ \\ ${ }^{1}$ Department of Urology, Charles University in Prague, Faculty of Medicine, Faculty Hospital, Pilsen, Czech Republic \\ ${ }^{2}$ Department of Radiology, Charles University in Prague, Faculty of Medicine, Faculty Hospital, Pilsen, Czech Republic \\ ${ }^{3}$ Department of Pathology, National University Health System, Singapore \\ ${ }^{4}$ Department of Pathology, Charles University in Prague, Faculty of Medicine, Faculty Hospital, Pilsen, Czech Republic
}

Videosurgery Miniinv 2014; 9 (3): 371-379

DOI: $10.5114 /$ wiitm.2014.43019

\begin{abstract}
Introduction: One way how to reduce morbidity and improve cosmesic of kidney surgery is single site laparoscopy. Relatively well described concept but without defined position in clincal practise.

Aim: To report of institutional experience with laparoendoscopic single-site surgery (LESS) nephrectomy (NE) and compare (matched case-control study) it with that of standard laparoscopic NE (LNE).

Material and methods: In the period 8/2011 to 10/2013, we performed 183 mini-invasive NE (132 tumours, 51 benign aetiology); 45 of them (24.6\%) were LESS, the rest LNE. The main but not absolute indications for LESS were: non-obese men, and less advanced tumours. In 13 patients undergoing LESS-NEs (28.9\%) there was a transumbilical approach. For the rest, a pararectal incision was performed and an accessory port was added in 31.1\% (14) - 2/22 (9.1\%) left sided, 12/23 (52.2\%) right sided. Twenty-four LESS-NE were performed by a more experienced surgeon (mean operation time (MOT) $73.1 \mathrm{~min}$ ), 21 LESS-NE by 4 other surgeons (MOT $132.8 \mathrm{~min}$ ). These 24 were compared with 43 LNE done by the same surgeon before the period of LESS (1/2007-8/2011) and with similar characteristics of cases (body mass index (BMI) $\leq 35 \mathrm{~kg} / \mathrm{m}^{2}$, less advanced tumour).

Results: We found no statistically significant differences in any of the parameters studied. The MOT $73.1 \mathrm{~min}$ vs. $75.0 \mathrm{~min}$ ( $p=0.78), B M I 27.4 \mathrm{~kg} / \mathrm{m}^{2}$ vs. $29.2 \mathrm{~kg} / \mathrm{m}^{2}$ ( $\left.p=0.08\right)$, blood loss 54.7 vs. $39.2(p=0.47)$. Complications (4.2\% vs. 11.6\%) were only of internal character in origin. No conversion in either group. In LESS-NE, staplers were used more frequently (more expensive than clips) for division of renal hilar vessels (70.8\% vs. 51.2\%). The mean price of LESS-NE was $€ 367$ higher. Conclusions: The LESS NE performed by an experienced surgeon is a safe and efficient method for the surgical treatment of both malignant and benign renal conditions in patients with $B M I<30 \mathrm{~kg} / \mathrm{m}^{2}$ and with low-stage tumours. The LESS NE is more expensive compared to LNE.
\end{abstract}

Key words: kidney tumour, nephrectomy, laparoscopy, laparoendoscopic single-site surgery.

\section{Introduction}

Laparoscopic nephrectomy (LNE) is a commonly employed method for the surgical treatment of both benign and malignant renal diseases [1-3]. In order to minimize the surgical trauma a minilaparoscopic ap- proach, using instruments $2-3 \mathrm{~mm}$ in size, single port laparoscopy - laparo-endoscopic single-site surgery (LESS) and natural orifice transluminal endoscopic surgery (NOTES) - is useful. From a purely cosmetic point of view, laparoscopy with hidden incisions can 
be performed [4, 5]. However, minilaparoscopy does not change the concept of standard laparoscopy. The main difference is that some ports are replaced by $2-3 \mathrm{~mm}$ instruments. The main topic for progress in contemporary miniinvasive laparoscopic surgery is single port laparoscopy (surgery) - LESS. Various acronyms have been designated for this approach/ technique $[5,6]$. The urologic NOTES Working Group suggested as a consensus nomenclature the acronym LESS, as a general term for all new surgical procedures using one skin incision for access of camera and instruments, with or without an additional port of maximum $5 \mathrm{~mm}$ [6]. With one additional port, the term hybrid LESS may be used [7]. Nephrectomy (NE) seems to be the most important LESS surgery for clinical practice in urology, even in children [8]. The concept of LESS may also be applied to other urological, surgical and gynaecological procedures [2, 5, 9-12]. The LESS-NE is indicated mainly in selected cases (young, non-obese, non-neoplastic conditions (but if so, low-stage disease)) and this technique can replace about $50 \%$ of LNE [13]. Some authors however have applied LESS in more complicated situations such as larger tumours and previous abdominal surgery [14, 15]. Oncological results are comparable with LNE [3].

\section{Aim}

In this paper, we have, based on our experience, assessed the possible role of LESS-NE in everyday clinical practice as compared to standard (conventional) LNE.

\section{Material and methods}

We started performing LESS NE in 8/2011. Until 10/2013, we performed 183 miniinvasive laparosco-

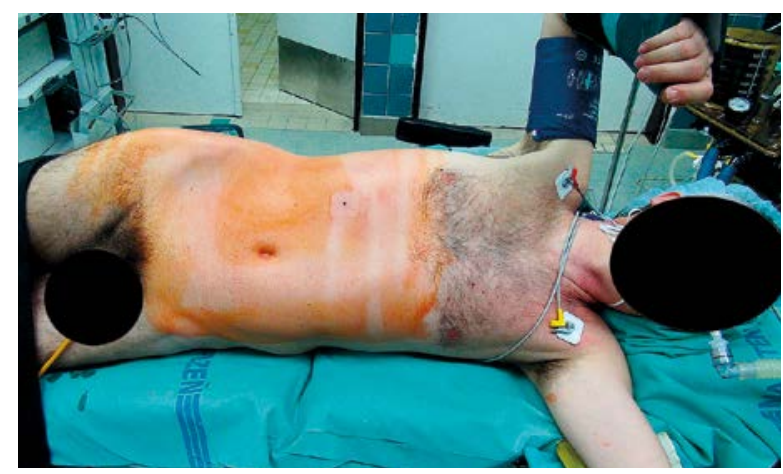

Photo 1. A lateral decubitus position with slight table break at the waist for the right side LESS-NE pic NE including LESS nephrectomies (132 for malignant neoplasms and 51 for non-neoplastic aetiology). The LESS technique was used in $24.6 \%(n=45)$ of them (33 for neoplasms and 12 for non-neoplastic aetiology). Thirteen (28.9\%) were by transumbilical approaches, the rest pararectal incision. The LESS-NE constituted in 2011 (9-12) 20.7\% of all miniinvasive NE (6/29), in $201219.8 \%$ (16/81) and in 1-10/2013 $31.5 \%(23 / 73)$.

\section{Patient selection}

Patients indicated for LESS-NE were subselected from those indicated for LNE. The decision on what procedure to perform did not follow any standardized approach. The main but not strict indications were: non-obese, and less advanced tumours. And a surgeon able to perform the LESS technique was available at the time of the operation. The LESS was performed by five genito-urinary surgeons with varying experience of laparoscopic surgery. Two additional genito-urinary surgeons performed only standard LNE.

\section{Operative technique}

We have adopted the technique described by the Stolzenburg group $[2,16]$. The patient is under general anaesthesia with a urethral catheter and he/she is placed in a lateral decubitus position with a slight table break at the waist (Photo 1). Through about $4 \mathrm{~cm}$ small peri-umbilical (only slim patient and more skilled surgeon) or pararectal incision a multi-channel single port Quadport $+{ }^{\circledR}$ Olympus is inserted (Photo 2). We employ a standard rigid straight full HD laparoscopic camera $10 \mathrm{~mm} 0^{\circ}$ and only two $5 \mathrm{~mm}$ working instruments at the same moment. One prebent grasper (during the whole operation) and one standard straight instrument - mainly any sealing device (harmonic scalpel of different brands, Ligasure 35 mm Blunt Tip ${ }^{\circledR}$, Thunderbeat $^{\circledR}$ or EnSeal ${ }^{\circledR}$ ) - are used (see Table I). The straight instrument is replaced sometimes with suction, hook with electrocautery, clip applicator, bipolar forceps, scissors or stapler. Dorsal peritoneum is incised laterally to the colon. Gerota's fascia is opened longitudinally and medially to the kidney. The ureter is liberated and elevated with thread with a straight needle inserted through the lateral part of the abdominal wall (Photos 3, 4). The area of hilar vessels is visualised by this manoeuvre. In some cases with the need 


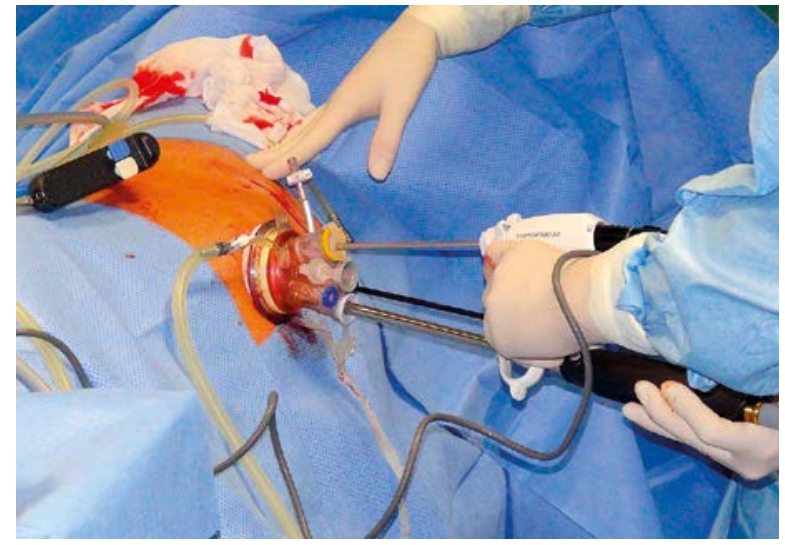

Photo 2. Quadport+ ${ }^{\circledR}$ with 5 channels. The white $10 \mathrm{~mm}$ channel with optic $10 \mathrm{~mm}^{\circ}$, two blue $5 \mathrm{~mm}$ for working instruments (one pre-bent grasper, the second for sealing device or suction), grey $12 \mathrm{~mm}$ (with possible reduction for $5 \mathrm{~mm}$ ) used for stapler or clips and yellow $15 \mathrm{~mm}$ (with possible reduction to $5 \mathrm{~mm}$ ) used for Endo Catch bag $^{\circledast}$ or alternatively (on picture) for sealing instrument - less collision with other instruments than if introduced through the blue one)

to elevate the liver or spleen, a $3 \mathrm{~mm}$ grasper is inserted directly through the abdominal wall (without the need for a trocar) in the hypochondrium close to the end of the $12^{\text {th }}$ rib with previous opening of the peritoneum with $3 \mathrm{~mm}$ scissors (Photos 5, 6). Renal vessels are carefully prepared using a sealing device and/or hook with electrocautery. At this step, biphasic computed tomography (CT) or magnetic resonance imaging (MRI) angiography is helpful for better planning of the operation $[17,18]$. The hilar vessels are divided by two methods: (1) EndoGIA ${ }^{\mathrm{TM}}$ stapler with articulating tip en bloc. It is faster, more expensive, suitable even for a less skilled surgeon than the second option: (2) Renal artery is liberated and divided with the help of 3 (2 medially and 1 laterally to final cut) plastic clips with lock (Hem-o-lok ${ }^{\circledR}$ Weck, Teleflex, size $L$ ). The renal vein is divided then by the same principle; only clips of size $\mathrm{XL}$ are used (Photo 4). After the control of renal vasculature, the ureter is cut and the whole kidney is mobilized with any sealing device (see Table I). The specimen is placed in the $15-\mathrm{mm}$ Endo Catch bag ${ }^{\circledast}$ (Covidien). The Quadport $+{ }^{\circledR}$ is removed and minilaparotomy is extended to facilitate removing the specimen from the abdominal cavity. Minilaparotomy is closed without insertion of a drain (Photo 7) [19]. In contrast, we drain the nephrectomy bed in all LNE cases.
Table I. Results of all 45 LESS-NE in detail

\begin{tabular}{|c|c|c|c|c|c|c|c|}
\hline \multirow{2}{*}{\multicolumn{2}{|c|}{$\begin{array}{l}\text { Variable } \\
\text { Total number }\end{array}$}} & \multicolumn{2}{|c|}{ Together } & \multicolumn{2}{|c|}{$\begin{array}{l}\text { The most } \\
\text { experienced } \\
\text { surgeon }\end{array}$} & \multicolumn{2}{|c|}{$\begin{array}{c}\text { Other } \\
\text { surgeons }\end{array}$} \\
\hline & & 45 & & 24 & $53.3 \%$ & 21 & $46.7 \%$ \\
\hline \multirow[t]{2}{*}{ Site } & Left & 22 & $48.9 \%$ & & & & \\
\hline & Right & 23 & $51.1 \%$ & & & & \\
\hline \multirow[t]{2}{*}{ Gender } & Female & 25 & $55.6 \%$ & & & & \\
\hline & Male & 20 & $44.4 \%$ & & & & \\
\hline \multirow{4}{*}{$\begin{array}{l}\mathrm{BMI} \\
{\left[\mathrm{kg} / \mathrm{m}^{2}\right]}\end{array}$} & Mean & 27.5 & & & & & \\
\hline & SD & 3.9 & & & & & \\
\hline & Min. & 16.0 & & & & & \\
\hline & Max. & 33.2 & & & & & \\
\hline \multirow{4}{*}{$\begin{array}{l}\text { Size of } \\
\text { tumour } \\
{[\mathrm{mm}]}\end{array}$} & Mean & 51.6 & & & & & \\
\hline & SD & 16.9 & & & & & \\
\hline & Min. & 11.0 & & & & & \\
\hline & Max. & 80.0 & & & & & \\
\hline \multirow{4}{*}{$\begin{array}{l}\text { Time of } \\
\text { surgery }\end{array}$} & Mean & 99.2 & & & 73.1 & & 132.8 \\
\hline & SD & 43.1 & & & 18.4 & & 41.1 \\
\hline & Min. & 37 & & & 37.0 & & 85.0 \\
\hline & Max. & 230 & & & 00.0 & & 230.0 \\
\hline \multirow{4}{*}{$\begin{array}{l}\text { Blood } \\
\text { loss }\end{array}$} & Mean & 76.3 & & & & & \\
\hline & SD & 156.6 & & & & & \\
\hline & Min. & 0 & & & & & \\
\hline & Max. & 800 & & & & & \\
\hline \multirow{4}{*}{$\begin{array}{l}\text { Weight } \\
\text { of speci- } \\
\text { men }\end{array}$} & Mean & 402.2 & & & & & \\
\hline & SD & 167.6 & & & & & \\
\hline & Min. & 135 & & & & & \\
\hline & Max. & 750 & & & & & \\
\hline \multirow{2}{*}{$\begin{array}{l}\text { Division } \\
\text { of hilar } \\
\text { vessels }\end{array}$} & Clips & 9 & $20.0 \%$ & & & & \\
\hline & Stapler & 36 & $80.0 \%$ & & & & \\
\hline $\begin{array}{l}\text { Added } \\
\text { port(s) }\end{array}$ & & 14 & $31.1 \%$ & 8 & $33 \%$ & 6 & $29 \%$ \\
\hline $\begin{array}{l}\text { Paraumb } \\
\text { approach }\end{array}$ & ilical & 13 & $28.9 \%$ & & & & \\
\hline \multirow{4}{*}{$\begin{array}{l}\text { Sealing } \\
\text { device }\end{array}$} & $\mathrm{HS}$ & 6 & $13.3 \%$ & & & & \\
\hline & LS & 29 & $64.4 \%$ & & & & \\
\hline & TB & 9 & $20.0 \%$ & & & & \\
\hline & ES & 1 & $2.2 \%$ & & & & \\
\hline $\begin{array}{l}\text { Compli- } \\
\text { cations }\end{array}$ & & 3 & $6.7 \%$ & 1 & $4.2 \%$ & 2 & $9.5 \%$ \\
\hline
\end{tabular}

ES - EnSeal ${ }^{\oplus}$ G2 Johnson \& Johnson, HS - Harmonic scalpel (Harmonic Ace ${ }^{\oplus}$ Johnson \& Johnson or Sonicison ${ }^{\oplus}$ Covidien or Sonicbeat ${ }^{\oplus}$ Olympus), LS V+ - Ligasure ${ }^{\oplus}$ Blunt Tip $35 \mathrm{~mm}^{\circledast}$ Covidien, TB - Thunderbeat ${ }^{\circledast}$ Olympus. In 3 cases (6.7\%), a $12 \mathrm{~mm}$ port was used in addition to the $5 \mathrm{~mm}$ port, i.e. conversion to standard laparoscopy. Complications $-2 \times$ Clavien 2 [22] (light cerebral stroke and acceleration of hypertension) and $1 \times 3 a$ (wound infection) 


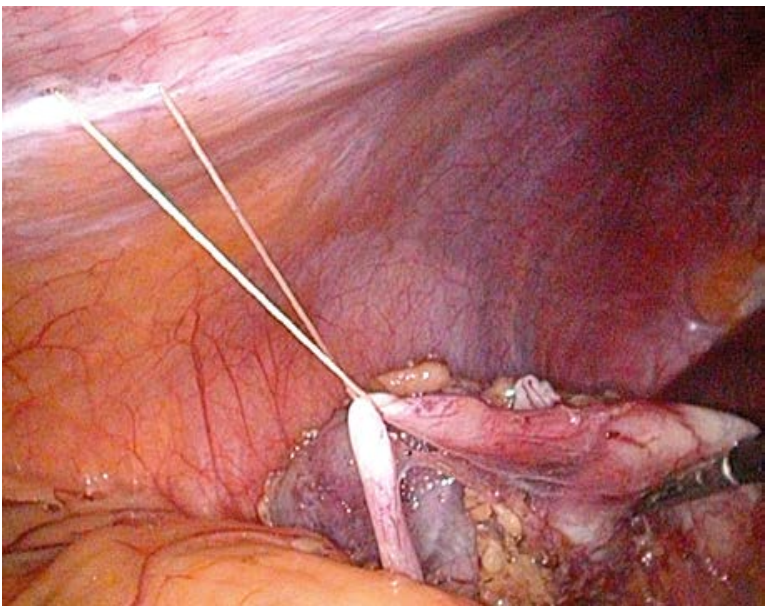

Photo 3. The right ureter elevated with thread introduced through abdominal wall with straight needle

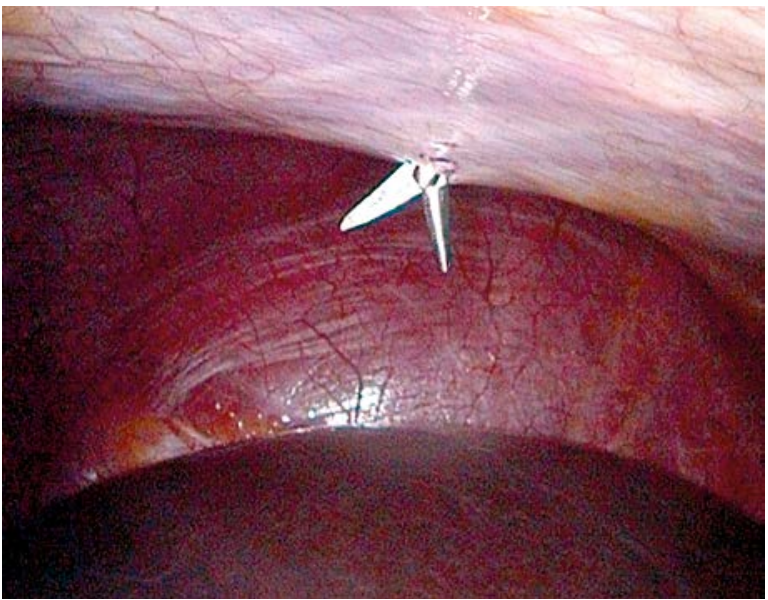

Photo $5.3 \mathrm{~mm}$ scissors introduced through the abdominal wall cut the peritoneum to allow subsequently insertion of the $3 \mathrm{~mm}$ grasper (see Photo 6)

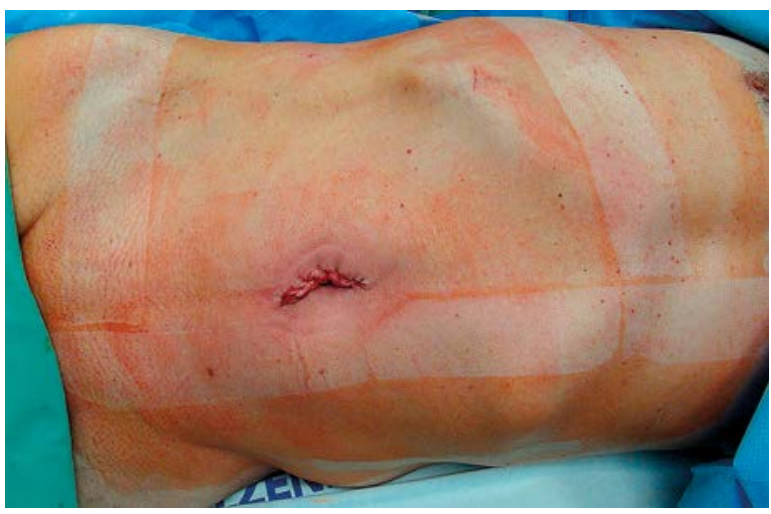

Photo 7. Abdominal wall of 60-year-old man following radical right side LESS-NE

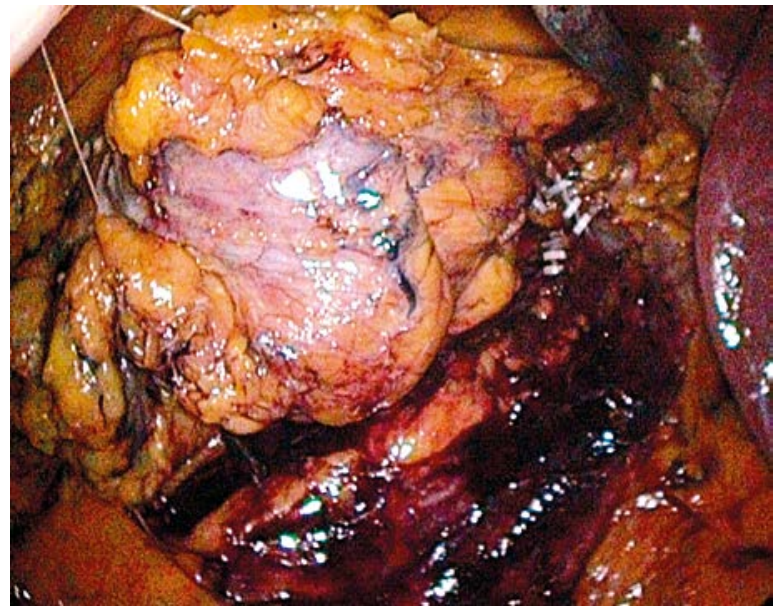

Photo 4. Thread with straight needle introduced through abdominal wall is used in that case not for elevation of ureter, but the lower pole with tumour $60 \mathrm{~mm}$ of the right kidney. The renal artery is divided with Hem-o-lok ${ }^{\circledR}$ clips size $L$ and three clips size $\mathrm{XL}$ are applied on the renal vein

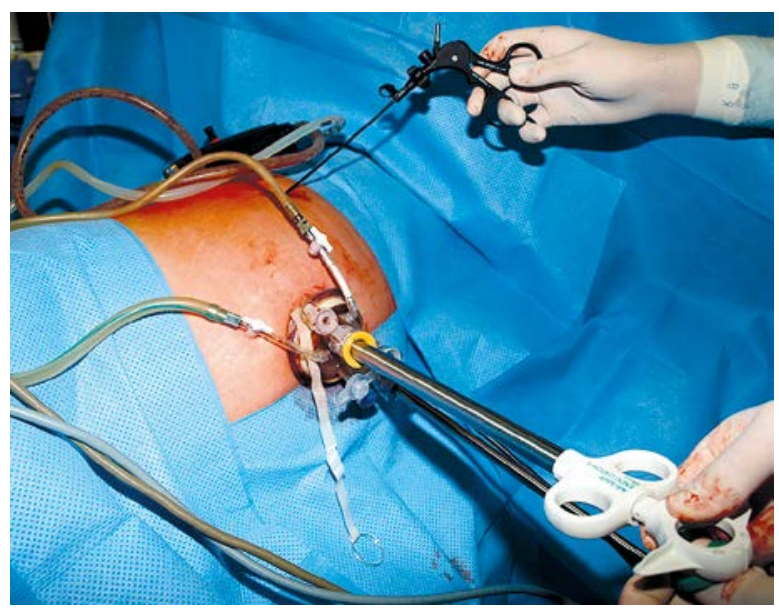

Photo 6. Additional $3 \mathrm{~mm}$ grasper to elevate liver at the right side nephrectomy. The Endo Catch bag ${ }^{\circledast}$ (Covidien) is introduced through the $15 \mathrm{~mm}$ channel

Twenty-four LESS-NE were performed by the more experienced surgeon (mean operation time $73.1 \mathrm{~min}$ ), 21 LESS-NE by 3 other surgeons (mean time: $132.8 \mathrm{~min}$ ). These 24 cases of the more experienced surgeon were compared with 43 LNE done by the same surgeon (1/2007-8/2011) and with similar characteristics (body mass index $(\mathrm{BMI}) \leq 35 \mathrm{~kg} /$ $\mathrm{m}^{2}$, less advanced tumour). The LNE were performed transperitoneally through 4 (or 5 on the right side); the technique was described formerly [20, 21]. 


\section{Results}

Results are shown in detail in Table I (all 45 LESS-NE) and Table II (comparison of LESS-NE vs. LNE in the most experienced surgeon). In comparison (24 LESSNE vs. 43 LNE as a matched case-control study), there were found no statistically significant differences

Table II. Comparison of similar cases of LNE vs. LESS-NE as a matched case-control study (the same surgeon, $\mathrm{BMI}<35 \mathrm{~kg} / \mathrm{m}^{2}$, less advanced kidney tumour - T1-2aNO). For statistics, Student's $t$-test was used

\begin{tabular}{|c|c|c|c|c|c|c|}
\hline \multirow[t]{2}{*}{ Variable } & & \multicolumn{2}{|c|}{ LNE } & \multicolumn{2}{|c|}{ LESS-NE } & \multirow[t]{2}{*}{ Value of $p$} \\
\hline & & $n$ & $\%$ & $n$ & $\%$ & \\
\hline Number & & \multicolumn{2}{|c|}{43} & \multicolumn{2}{|l|}{24} & \\
\hline Male & & 33 & 76.7 & 11 & 45.8 & \\
\hline Female & & 10 & 23.3 & 13 & 54.2 & \\
\hline \multirow[t]{4}{*}{ Age [years] } & Mean & \multicolumn{2}{|c|}{60.2} & \multicolumn{2}{|l|}{62.4} & 0.245541 \\
\hline & SD & \multicolumn{2}{|c|}{15.1} & \multicolumn{2}{|l|}{10.6} & \\
\hline & Min. & \multicolumn{2}{|c|}{25.9} & \multicolumn{2}{|l|}{36.5} & \\
\hline & Max. & \multicolumn{2}{|c|}{87.4} & \multicolumn{2}{|l|}{85.3} & \\
\hline \multirow[t]{4}{*}{ BMI $\left[\mathrm{kg} / \mathrm{m}^{2}\right]$} & Mean & \multicolumn{2}{|c|}{27.4} & \multicolumn{2}{|l|}{29.2} & 0.045446 \\
\hline & SD & \multicolumn{2}{|c|}{4.1} & \multicolumn{2}{|l|}{3.2} & \\
\hline & Min. & \multicolumn{2}{|c|}{16.0} & \multicolumn{2}{|l|}{23.0} & \\
\hline & Max. & \multicolumn{2}{|c|}{33.2} & \multicolumn{2}{|l|}{35.0} & \\
\hline Left & & 20 & 46.5 & 9 & 37.5 & \\
\hline Right & & 23 & 53.5 & 15 & 62.5 & \\
\hline \multirow[t]{4}{*}{ Time of surgery } & Mean & \multicolumn{2}{|c|}{75.0} & \multicolumn{2}{|l|}{73.1} & 0.784212 \\
\hline & SD & & & 18.4 & & \\
\hline & Min. & & & 37.0 & & \\
\hline & Max. & & & 100.0 & & \\
\hline Blood loss & Mean & & & 39.2 & & 0.465228 \\
\hline & SD & & & 86.6 & & \\
\hline & Min. & & & 0.0 & & \\
\hline & Max. & & & 400.0 & & \\
\hline Weight of specimen & Mean & & & 393.5 & & 0.000645 \\
\hline & SD & & & 158.7 & & \\
\hline & Min. & & & 190.0 & & \\
\hline & Max. & & & 750.0 & & \\
\hline Division of hilar vessels & Clips & 21 & 48.8 & 7 & 29.2 & \\
\hline & Stapler & 22 & 51.2 & 17 & 70.8 & \\
\hline Discharge from hospital & Mean & & & 4.8 & & 0.143228 \\
\hline (postoperative day) & SD & & & 1.6 & & \\
\hline & Min. & & & 2.0 & & \\
\hline & Max. & & & 10.0 & & \\
\hline Size of tumour & Mean & & & 53.4 & & $0.119044^{*}$ \\
\hline & SD & & & 15.4 & & \\
\hline & Min. & & & 30.0 & & \\
\hline & Max. & & & 80.0 & & \\
\hline
\end{tabular}

Max. - maximal value, min. - minimal value, SD - standard deviation, *in LESS group, only 19 tumours, without Gaussian distribution (Student's t-test is suboptimal). For complications see text of article (results section) 
in any of the relevant parameters studied. The mean operation time was $73.1 \mathrm{~min}$ vs. $75.0 \mathrm{~min}(p=0.78$, Student's t-test), BMI $27.4 \mathrm{~kg} / \mathrm{m}^{2}$ vs. $29.2 \mathrm{~kg} / \mathrm{m}^{2}$ ( $p=0.045)$, blood loss 54.7 vs. $39.2(p=0.47)$. The only significant difference was in weight of the specimen. This can be explained, such that even in non-obese patients, the adipose renal capsule can be voluminous. This can be assessed by CT scan. Regrettably, we do not have any exact criteria to quantitatively express this and these cases are more frequently referred for standard LNE. Complications occurred with similar frequency in both groups $(4.2 \%$ vs. $11.6 \%$ ) but were almost exclusively of internal character. In LESS-NE: Clavien II [22] 1x: acceleration of hypertension, In LNE - Clavien I 1x: wound infection, Clavien II 2x: pulmonary embolisms combined with haemodialysis (due to LNE of solitary kidney) and aspiration at the end of anaesthesia, Clavien
III 1x: occlusion of femoro-popliteal arterial bypass with need of thrombectomy with Fogarty catheter. No conversion to open surgery was required in any of the groups. An accessory port was added in 31.1\% ( $n=14$ among 45 cases) in the whole LESS-NE group. An additional port was added more frequently on the right side $(52.2 \%, 12 / 23)$ than on the left side (9.1\%, 2/22). In LESS-NE, staplers (more expensive than clips) were used more frequently for division of renal hilar vessels (70.8\% vs. $51.2 \%)$. The mean price of LESS-NE was €367 higher (see Table III).

\section{Discussion}

The initial clinical studies on LESS surgery in urology including NE were published in 2007-2008 [23-26]. At that time, most urologists considered LESS and NOTES to be experimental methods under development. Since then we have witnessed fast

Table III. Difference of price between LNE and LESS-NE

\begin{tabular}{|c|c|c|c|c|c|c|c|}
\hline \multicolumn{4}{|c|}{ Difference of price between LNE and LESS-NE } & \multirow{2}{*}{$\begin{array}{c}\text { LESS-NE } \\
24\end{array}$} & \multirow{2}{*}{$\begin{array}{c}\text { LNE } \\
43\end{array}$} & \multirow{4}{*}{$\begin{array}{l}\text { LESS-NE - } \\
\text { expenses } \\
\text { together }\end{array}$} & \multirow{4}{*}{$\begin{array}{l}\text { LNE - } \\
\text { expenses } \\
\text { together }\end{array}$} \\
\hline Total no. of cases & & & & & & & \\
\hline \multirow[t]{2}{*}{ Equipment } & \multirow[t]{2}{*}{$\begin{array}{c}\text { Price } \\
\text { per item }\end{array}$} & \multicolumn{2}{|c|}{$\begin{array}{l}\text { Items used per } \\
\text { case }\end{array}$} & \multirow{2}{*}{\multicolumn{2}{|c|}{ Number of cases }} & & \\
\hline & & LNE & LESS-NE & & & & \\
\hline Veress needle & 1258 & 1 & 0 & 0 & 23 & 0 & 28934 \\
\hline Quadport+ & 13299 & 0 & 1 & 24 & 0 & 319176 & 0 \\
\hline Trocar $12 \mathrm{~mm}$ & 1197 & 1 & 0 & 0 & 43 & 0 & 51471 \\
\hline Trocar 5 mm - left side (2 pieces) & 1331 & 2 & 0 & 0 & 20 & 0 & 53240 \\
\hline Trocar $5 \mathrm{~mm}$ - right side (3 pieces) & 1331 & 3 & 0 & 0 & 23 & 0 & 91839 \\
\hline Stapler - applicator & 3026 & 1 & 1 & 17 & 22 & 51442 & 66572 \\
\hline Stapler - cartridge 45 mm & 4025 & 1 & 1 & 17 & 22 & 68425 & 88550 \\
\hline Hem-o-lok clips size L (6 pieces) & 383 & 1 & 1 & 7 & 17 & 2681 & 6511 \\
\hline Hem-o-lok clips size XL (6 pieces) & 432 & 1 & 1 & 7 & 17 & 3024 & 7344 \\
\hline Ligasure 35 mm blunt tip & 11470 & 1 & 1 & 24 & 43 & 275280 & 493210 \\
\hline Endo Catch bag 15 mm & 2822 & 1 & 1 & 24 & 43 & 67728 & 121346 \\
\hline Expenses together for all LESS-NE & & & & & & 787756 & 1009017 \\
\hline Mean price per case (CZK) & & & & & & 32823.2 & 23465,5 \\
\hline Mean price per case $[€]$ & & & & & & 1287.2 & 920,2 \\
\hline Difference per case $[€]$ & & & & & & & \\
\hline
\end{tabular}

The prices are in CZK (Czech crown) including VAT (value added tax), only final results are converted to $€$ (EURO). Ratio is 25.5 CZK for $€ 1$. Due to the same mean time of both operations, prices for operating theatre, employees (physicians, nurse etc.) are not included 
development of equipment and surgical techniques pertaining to LESS in many urological procedural settings, especially for NE. Currently, LESS-NE is a validated and reproducible method and this technique should, in contemporary urological surgery, constitute a treatment option for selected patients.

In order to perform LESS-NE, some basic questions have to be addressed. The most prudent is whether LESS-NE offers any advantages to my patients. If yes, what patients are suitable for this technique? Other issues that need to be contemplated are: What equipment should be used? What should the technical approach be? And what experience should the surgeon have?

Surgeons performing LESS-NE compare this procedure with LNE based on retrospective data and rarely with prospective randomised trials. In a review article dealing with 2 randomises clinical trials (RCT) and 25 retrospective studies, altogether 1094 patients of LESS-NE were identified. The LESS-NE was found to be a safe and efficient alternative to LNE with less pain, shorter recovery time and a better cosmetic effect [27]. The data were corroborated by match paired studies [3, 28]. Greco et al. [29] measured acute-phase markers (C-reactive protein, serum amyloid A antibody, interleukin 6 add 10) and they concluded that LESS does not add any significant advantage in comparison with traditional radical LNE in terms of systemic stress response and surgical trauma. Regarding the surgical trauma, we cannot clearly prove advantages of LESS-NE, but we feel that performing three more incisions is inferior to just making one (about $4 \mathrm{~cm}$ in length - finally used for extraction of the specimen). It cannot be overemphasized that LESS-NE should only be considered in well-selected patients and performed by an experienced surgeon (performing standard LNE absolutely routinely).

The LESS-NE is suitable mainly for easier cases (i.e. patients with $\mathrm{BMI}<30 \mathrm{~kg} / \mathrm{m}^{2}$ and smaller/less advanced kidney tumours). Currently, LESS-NE constitutes about $1 / 3$ of miniinvasive NEs. However, in some institutions the figure approaches 50\% [13].

Regarding equipment which requires ports, instruments and cameras/optics, there are several different systems on the market. Excellent reviews dealing with this topic (of equipment) have been published recently $[2,5,9]$. For the ports, one can use standard ports introduced at one site, gel ports allowing the introduction of normal ports (GelPort ${ }^{\oplus}$ and GelPOINT ${ }^{\oplus}$ Applied Medical), "home-made" entrances allowing introduction of normal ports or special multilumen ports ("R-port" - mainly Quadport $+{ }^{\oplus}$ Olympus, X-CONE ${ }^{\oplus}$ and ENDOCONE ${ }^{\oplus}$ of Storz, Key Port ${ }^{\oplus}$ Richard Wolf, SILS Covidien, Pnavel system Uni- $X^{\oplus}$, OCTO $^{\text {TM }}$ Port, DaLimSurginet and special system SPIDER, Transenterix). The multi-lumen ports must be combined with special instruments (flexible or bent) and special optics can be of advantage, mainly with a flexible tip inside the abdomen, thereby eliminating or reducing the risk of clashing the camera with instruments. For cases in need of an additional port, we prefer miniature (needlescopic) instruments 3 (2) $\mathrm{mm}$ in diameter. Before starting our LESS procedures we trained on an animal model (Leipzig, Germany) with equipment of Olympus (Triport ${ }^{\oplus}$ and Quadport $^{\oplus}$ and pre-bent instruments and flexible cameras). Due to this, we started to employ this equipment. Presently, LESS-NE is standardised at our department and we are probably ready to try the next system with the main goal to reduce cost.

Regarding the surgical technique, there are two main issues: (1) the site of approach and (2) the division of the hilar vessels. The best cosmetic effect is acquired with a paraumbilical approach, but it can be more challenging than pararectal. We consider the pararectal approach generally to be easier due to direct access to the kidney, overcoming the interference of the bowel, and this gives better access to the hilar vessels and for liberation of the upper pole of the kidney. Due to this reason, we have used the pararectal approach even in some none-obese patients (mainly in the first 20 cases in this series). Pararectal incision is recommended by Stolzenburg [2] in obese patients. But some authors prefer this approach in all cases [30]. For the division of hilar vessels, it is more challenging to apply lockable clips even in LNE [21]. In LESS-NE, separation and liberation of the hilar vessel and application of clips are more difficult, due to (1) using only two instruments (one of them being a pre-bent grasper, frequently used for elevation of the liver and other tissues, the second a direct dissector or clip applicator) and (2) due to clashing of clip applicator with the camera. Because of this, the stapler is applied more frequently in LESS-NE than in LNE (73.9\% vs. $51.2 \%)$. Also, more frequent application of the stapler requires special expensive multichannel ports, which explains the higher price of LESS-NE. 


\section{Conclusions}

Currently, LESS NE is indicated at our institution in patients with a $\mathrm{BMI}<30 \mathrm{~kg} / \mathrm{m}^{2}$ and in patients with small, low-stage renal tumours. It is a safe and relatively fast method, but only if performed by an experienced surgeon. The operation time is longer when performed by a less experience surgeon. Compared to LNE, LESS NE is more expensive (€367). Conversion to standard laparoscopy is rare. Multi-institutional randomised trials are required to confirm benefits and safety of LESS-NE.

\section{Acknowledgments}

The work was supported by the Charles University Research Fund (project number P36), by Ministry of Health, Czech Republic - conceptual development of research organization (Faculty Hospital in Pilsen FNPI, 00669806) and by grant IGA NT 12010-4.

\section{References}

1. Ljungberg B, Cowan NC, Hanbury DC, et al.; European Association of Urology Guideline Group. EAU guidelines on renal cell carcinoma: the 2010 update. Eur Urol 2010; 58: 398-406.

2. Stolzenburg JU, Kallidonis P, Ragavan N, et al. Clinical outcomes of laparo-endoscopic single-site surgery radical nephrectomy. World J Urol 2012; 30: 589-96.

3. Antonelli JA, Bagrodia A, Odom C, et al. Laparoendoscopic single-site nephrectomy compared with conventional laparoscopic nephrectomy: a 5-year, single-surgeon experience. Eur Urol 2013; 64: 412-8.

4. Gargollo PC. Hidden incision endoscopic surgery: description of technique, parental satisfaction and applications. J Urol 2011; 185: 1425-31.

5. Eret V, Schmidt M, Stránský P, et al. Laparoendoscopic single-site surgery (LESS) in urology - a new frontier in minimally invasive surgery? Čes Urol 2012; 16: 146-56.

6. Box G, Averch T, Cadeddu J, et al.; Urologic NOTES Working Group. Nomenclature of natural orifice translumenal endoscopic surgery (NOTES) and laparoendoscopic single-site surgery (LESS) procedures in urology. J Endourol 2008; 22: 2575-81.

7. Georgiou AN, Rassweiler J, Herrmann TR, et al. Evolution and simplified terminology of natural orifice transluminal endoscopic surgery (NOTES), laparoendoscopic single-site surgery (LESS), and mini-laparoscopy (ML). World J Urol 2012; 30: 573-80.

8. Bryks-Laszkowska A, Gołębiewski A, Czauderna P. Laparoscopic single port surgery nephrectomy in a child - initial experience. Videosurgery Miniinv 2012; 7: 304-6.

9. Autorino R, Cadeddu JA, Desai MM, et al. Laparoendoscopic single-site and natural orifice transluminal endoscopic surgery in urology: a critical analysis of the literature. Eur Urol 2011; 59: 26-45.

10. Kurpiewski W, Pesta W, Kowalczyk M, et al. The outcomes of SILS cholecystectomy in comparison with classic four-trocar laparoscopic cholecystectomy. Videosurgery Miniinv 2012; 7 : 286-93.

11. Beiša V, Kildušis E, Strupas K. Single access retroperitoneoscopic adrenalectomy: initial experience. Videosurgery Miniinv 2012; 7 : 45-9.

12. Pędziwiatr M, Matłok M, Major P, et al. Laparoscopic surgery of the spleen through single umbilical incision. Videosurgery Miniinv 2013; 8: 8-12.

13. Mir SA, Best SL, Donnally CJ 3rd, et al. Minimally invasive nephrectomy: the influence of laparoendoscopic single-site surgery on patient selection, outcomes, and morbidity. Urology 2011; 77: 631-4.

14. Springer C, Inferrera A, Kawan F, et al. Laparoendoscopic single-site versus conventional laparoscopic radical nephrectomy for renal cell cancer in patients with increased comorbidities and previous abdominal surgery: preliminary results of a single-centre retrospective study. World J Urol 2013; 31: 213-8.

15. Rosoff JS, Fine RG, Velez MC, Del Pizzo JJ. Laparoendoscopic single-site radical nephrectomy for large renal masses. J Endourol 2013; 27: 34-39.

16. Stolzenburg JU, Kallidonis P, Hellawell G, et al. Technique of laparoscopic-endoscopic single-site surgery radical nephrectomy. Eur Urol 2009; 56: 644-50.

17. Hora M, Ferda J, Kreuzberg B, et al. The use of two-phase CT-angiography in the surgical treatment of renal tumours. Čes Urol 2005; 9: 14-9.

18. Hora M, Stránský P, Trávníček I, et al. Three-tesla MRI biphasic angiography: a method for preoperative assessment of the vascular supply in renal tumours-a surgical perspective. World J Urol 2013; 31: 1171-6.

19. Major P, Matłok M, Pędziwiatr M, Budzyński A. Do we really need routine drainage after laparoscopic adrenalectomy and splenectomy? Videosurgery Miniinv 2012; 7: 33-9.

20. Hora M, Klecka J Jr, Hes O, et al. Miniinvasive laparoscopic or retroperitoneoscopic radical nephrectomy for the parenchymal tumor. Rozhl Chir 2005; 84: 246-52.

21. Hora M, Klečka J, Eret V, Ferda J. Hilar vascular occlusion during laparoscopic nephrectomy by means of locking clips. Čes Urol 2007; 11: 89-92.

22. Clavien PA, Barkun J, de Oliveira ML, et al. The Clavien-Dindo classification of surgical complications: five-year experience. Ann Surg 2009; 250: 187-96.

23. Rane A, Rao P, Bonadio F, Rao P. Single port laparoscopic nephrectomy using a novel laparoscopic port (R-Port) and evolution of single laparoscopic port procedure (SLiPP). J Endourol 2007; 21 (Suppl. 1): A287.

24. Raman JD, Bensalah K, Bagrodia A, et al. Laboratory and clinical development of single keyhole umbilical nephrectomy. Urology 2007; 70: 1039-42.

25. Desai MM, Rao PP, Aron M, et al. Scarless single port transumbilical nephrectomy and pyeloplasty: first clinical report. BJU 2008; 101: 83-8.

26. Kaouk JH, Haber GP, Goel RK, et al. Single-port laparoscopic surgery in urology: initial experience. Urology 2008; 71: 3-6.

27. Fan X, Lin T, Xu K, et al. Laparoendoscopic single-site nephrectomy compared with conventional laparoscopic nephrectomy: a systematic review and meta-analysis of comparative studies. Eur Urol 2012; 62: 601-12. 
28. Wang L, Liu B, Wu Z, et al. A matched-pair comparison of laparoendoscopic single-site surgery and standard laparoscopic radical nephrectomy by a single urologist. J Endourol 2012; 26: 676-81.

29. Greco F, Hoda MR, Mohammed N, et al. Laparoendoscopic single-site and conventional laparoscopic radical nephrectomy result in equivalent surgical trauma: preliminary results of a single-centre retrospective controlled study. Eur Urol 2012; 61: 1048-53.

30. Chłosta P, Drewa T, Obarzanowski M, et al. Do we need a cosmetic effect for radical nephrectomy? Laparoendoscopic single-site surgery would help to answer this question. Videosurgery Miniinv 2011; 6: 1-4.

Received: 26.10 .2013 , accepted: 2.12 .2013 